\title{
PEMBERDAYAAN KOMUNITAS BERBASIS APPRECIATIVE INQUIRY DI PULAU TUBEKET MENTAWAI SUMATRA BARAT
}

\begin{tabular}{|c|c|c|}
\hline \multicolumn{3}{|c|}{ P-ISSN: 2085-4536 | E-ISSN: 2721-7183 } \\
\hline \multicolumn{3}{|c|}{ Link: https://jurnal-stidnatsir.ac.id/index.php/binaummat/article/view/41 } \\
\hline \multicolumn{3}{|c|}{ DOI : $\underline{\text { https://doi.org/10.38214/jurnalbinaummatstidnatsir.v2i01.41 }}$} \\
\hline Dikirim: $25-03-2019$ & Direview: 05-04-2019 & Diterbitkan: 17-04-2019 \\
\hline \multicolumn{3}{|c|}{$\begin{array}{l}\text { AHMAD MISBAHUL ANAM } \\
\text { STID Mohammad Natsir, Indonesia } \\
\text { misbahulanam@stidnatsir.ac.id }\end{array}$} \\
\hline
\end{tabular}

\begin{abstract}
ABSTRAK
Tujuan Penelitian: Penelitian ini bertujuan untuk mengungkap pemberdayaan komunitas berbasis appreciative inquiry di Pulau Tubeket Mentawai Sumatra Barat. Metode Penelitian: Kualitatif. Hasil Penelitian: Dari sisi pendampingan, da'i menjadi aktor yang aktif memberikan penghargaan terhadap aktivitas dan potensi masyarakat dengan stimulus program yang lebih baik. Dari sisi pesan, tahapan-tahapan komunikasi bisa dilakukan dan dilewati dengan baik, melalui indikator keterlibatan masyarakat terhadap stimulus pertanyaan yang biasa digunakan dalam pendekatan appreciate inquiry yaitu, "Apa yang ada, apa yang mungkin, apa yang dapat, dan apa yang harus". Pedekatan dengan konsep menghargai, cukup efektif untuk menumbuhkan kesadaran masyarakat untuk berubah dan terlibat menggerakkan perubahan. Dalam hal perubahan pola pikir terkait pentingnya pendidikan dan perubahan pola pemenuhan bahan makan dari sagu ke beras, menjadi tolok ukur keberhasilan program pemberdayaan. Hasilnya, terhadap perubahan yang mereka lakukan, berdampak pada kemandirian dan penerimaan terhadap pola baru yang lebih modern. Kuncinya, sebagaimana yang dilakukan oleh da'i adalah penghargaan atas potensi yang mereka miliki, baik potensi manusianya, ataupun potensi alamnya sebagai media menjalani kehidupannya.
\end{abstract}

Kata kunci: Appreciate inquiry, pemberdayaan, Tubeket, da'wah

\section{PENDAHULUAN}


Indonesia adalah sedikit negara yang disebut dengan negara kepulauan. Pulau-pulau berjajar dari kawasan pulau Sabang yang ada di wilayah Barat provinsi Aceh dan Merauke di wilayah Timur Papua. Dengan penduduk lebih dari 235 juta, ternyata belum seluruh pulau ditempati warganya. Ada pulau yang ditempati oleh warga, namun belum memiliki infrastruktur yang layak sebagai kawasan yang beradab. Hal tersebut terjadi karena kemampian negara untuk mengkaver fasilitas yang masih terbatas. Otonomi daerah yang telah dijadikan dasar pengembangan daerah, ternyata masih menyisakan pekerjaan rumah yang banyak.

Satu diantara pulau dengan penduduknya yang belum memiliki fasilitas yang layak, namun cukup kuat bertahan hidup adalah daerah Tubeket di kawasan Mentawai. Kepulauan Mentawai sendiri, terdiri dari tiga pulau besar; Sikakap, Sipora dan Siberut. Secara administrasi pemerintah, Sikakap memiliki tiga kecamatan yaitu dua di Pagai Utara; Sikakap dan Saumanganyak dan satu lagi di Pagai Selatan yaitu Malakopa. Sedangkan Kecamatan Pagai Selatan memiliki empat desa; Makalo, Sinakak, Bulasat dan Malakopa. Setiap desa kurang lebih memiliki enam dusun. Tubeket adalah salah satu dusun dari Desa Makalo Kecamatan Pagai Selatan Kabupaten Kepulauan Mentawai-Sumatra Barat dengan luas daerahnya $10 \mathrm{~km} 2$. Dusun ini terletak ke arah Utara Sikakapyang dapat dijangkau dengan memakai boat 15 PK selama 1 jam, menyisir samudera Indonesia dengan pemandangan laut yang indah dan menakjubkan.

Daerah ini terdiri dari 42 Kepala Keluarga $(\mathrm{KK})$ dengan jumlah penduduk 180 jiwa. Disamping beras, makanan pokok utama mereka adalah sagu dan keladi, sama dengan masyarakat kepulauan Mentawai pada umumnya. Untuk mendapatkan bahan makanan, terutama sagu penduduk laki-laki biasanya mencarinya ke hutan-hutan selama lima hari pulang pergi. Mereka belum memiliki teknologi untuk memindahkan tumbuhan sagu, tumbuhan khas daerah yang menempati kawasan itu ke daerah yang terdekat dengan tempat tinggal mereka, sehingga memerlukan waktu yang lama karena jarak hutan dan kampung dimana mereka tinggal.

Kecamatan Pagai Selatan ini mayoritas penduduknya beragama Kristen hanya dusun Boriai dan Tubeket saja semua penduduknya beragama Islam. Ini merupakan hasil dari gerakan kristenisasi yang semakin hari semakin gencar di Kepulauan Mentawai. Misalnya dusun Berkat, dahulu semua penduduk dusun ini beragama Islam yang diberi nama "Dusun Berkat Ilahi". Namun sekarang hampir seluruh penduduknya 
beragama Kristen hanya sebagian kecilnya saja yang beragama Islam sebanyak $7 \mathrm{KK}$. Semenjak itulah nama dusun tersebut diganti nama menjadi "Dusun Berkat". Apa yang terjadi di Dusun Berkat, begitu pula yang terjadi di daerah-daerah lainnya. Dusun Tubeket pun memiliki nasib yang hampir sama, ada penduduknya yang berpindah keagama Kristen karena faktor pernikahan, ekonomi, menganggap semua agama sama saja dan yang lainnya. Menyadari akan hal ini (gerakan permurtadan), segenap masyarakat dusun Tubeket telah membuat surat pernyataan bersama bahwa, "Setiap penduduk yang berpindah keagama Kristen harus keluar dari dusun Tubeket dan rumahnya dibongkar atau menjadi aset dusun Tubeket, dan setiap orang luar yang ingin berdomisili di dusun Tubeket harus beragama Islam atau terlebih dahulu masuk agama Islam bagi orang Kristen". Alhamdulillah, surat pernyataan ini sudah disetujui dan ditandatangani oleh segenap masyarakat.

Sampai tahun 2014 kawasan Tubeket hanya memiliki satu warga lakilaki yang menyelesaikan pendidikan tingkat pertama dan beberapa saja yang lulus sekolah tingkat dasar. Namun dari sisi kemandirian hidup mereka memiliki ketahanan yang mumpuni sebagai nelayanan, walaupun hanya untuk sekedar dapat mencukupi kebutuhan makan. Perkawinan dikawasan ini rata-rata dilaksanakan pada usia muda, kira-kira umur lulusan sekolah dasar. Hal ini terjadi karena mereka satu komunitas yang kecil sebagaimana kondisi diatas. Yang paling memprihatinkan adalah pada aspek kegiatan pendidikan, di dusun ini tidak ada unit pelaksana pendidikan satupun yang difasilitasi pemerintanh, apalagi layanan pendidikan agama. Ada beberapa anak yang sekolah, itupun terpaksa harus dipindahkan kepulau yang lebih besar di kota kecamatan Sikakap. Anak-anak itu hidup sendiri dan ala kadarnya dengan yang ada. Baru pada tahun antara 2011-2013 ada lembaga da'wah ${ }^{1}$ yang mencoba menempatkan dikawasan ini tenaga da'wah dengan program satu tahun dan masih berjalan sampai hari. Bahkan, pada tahun 2013 akhir, lembaga ini menginisiasi berdirinya panti anak-anak pulau agar mereka bisa tetap belajar dengan aman dengan bimbingan tenaga yang mumpuni di Sikakap.

Saat peneliti melakukan obeservasi dan tinggal di kawasan ini selama satu pekan, dan juga laporan da'i yang dikirimkan oleh Dewan Da'wah yang telah tinggal selama masa dua tahun, faktor kepercayaan adat, pendidikan

\footnotetext{
${ }^{1}$ Dewan Da'wah Islamiyah Indonesia
} 
dan ekonomi inilah yang mendominasi permasalahan masyarakat ini. Terutama ekonomi, yang menyangkut hajat hidup, bahan pokok dalam hal ini "sagu" telah menyita banyak waktu dan perhatian orang tua untuk ikut serta mendidik keluarga dan anak-anak. Bagaimana mereka akan memberikan perhatian kepada keluarga? Pemenuhan bahan pokok berupa 'sagu" telah banyak menyita waktu dan tenaga. Masjid-pun juga sepi dari kegiatan, dimana kumdandang adzan dan shalat jama'ah tidak bisa tertib dilakukan. Shalat jum'at hanya sesekali dilakukan saat kedatangan da'i. Maka setelah ada da'i menetap, shalat Jum'at menjadi tertib. Demikian juga dengan pendidikan anak-anak walaupun hanya dibuat sampai kelas tiga yang dirintis da'i dengan dibantu ibu guru lulusan sekolah dasar dan istri da'i yang ikut dalam masa tugas pengabdian da'wah dari Sekolah Tinggi Ilmu Da'wah Muhammad Natsir.

Dalam penelitian ini, peneliti akan mengungkapkan dua hal yang menarik dan cukup memberikan perubahan pada kominitas Tubeket sampai hari ini. Pertama, aspek pendidikan dimana anak-anak bisa mengikuti program pendidikan dan Kedua, aspek kebutuhan bahan pokok dari hasil usaha mereka dengan menanam padi di kawasan yang dekat dengan mereka tinggal. Dimana setelah ada pendidikan ini, anak-anak mendapatkan kesempatan lebih baik untuk melanjutkan pendidikan ke jenjang yang lebih tinggi di kota kecamatan yang berbeda pulau. Kecakapan pada skil pedidikan membantu mereka mengembangkan kemampuan berfikirm bercita-cita dan memilih kehidupan yang lebih baik. Sedang pada aspek kebutuhan pokok, sang da'i telah berhasil mengedukasi dan melakukan pembimbingan serta penguatan dalam memindahkan kawasan mendapatkan bahan pokok. Jika dahulu warga mencari sagu ke hutan, sekarang mereka bisa bercocok tanam di kampung sendiri, tanpa memerlukan waktu yang lama dan tenaga yang banyak. Keuntungannya, mereka bisa memberikan perhatian yang cukup kepada keluarga, meramaikan Masjid dan memperbaiki diri sendiri dengan mengikuti pembinaan rutin para orang tua yang dilakukan oleh da'i.

Penelitian ini memiliki pertaanyaan bagaimana sang "da'i" melakukan pemberdayaan melalui pendampingan dan penguatan kepada masyarakat Tubeket Mentawai Sumbar, sehingga memiliki kesadaran untuk mengubah dirinya?

Teori appreciative inquiry dipakai dalam penelitian ini, agar dapat melihat masyarakat dengan potensinya, dibanding masalahnya. Mengapa? 
Karena dalam kenyataanya suatu masyarakat selalu memiliki masalah yang sudah terlalu banyak sehingga memerlukan usaha untuk menutupnya mengalami kusulitan, sementara kemampuan untuk itu tidak sebanding. Selain itu, teori pengembangan masyarakt berdasar masalah sudah berjalan sangat lama dan dalam pendekatan masalah selalu masyarakat dipandang lemah dan pendonor atau pemeberi bantuan dipandang lebih hebat. Padahal belum tentu demikian, masyarakat sebenarnya individu atau kelompok yang memiliki keunikan yang sangat khas. Masalahnya hanya satu! Mereka belum menemuka mitra diskusi yang pas untuk membedah potensi yang mereka miliki. Jadi, bukan saja masalah yang sedang digali, tapi apa potensi yang dimiliki dan perlu distimulus agar lebih berdaya dan kuat.

Dalam melihat masyarakat Tubeket, pendekatan pemberdayaan ${ }^{2}$ lebih ditonjolkan sebagai usaha sadar mengakui keberdaan mereka dengan keberbagai keunikan hayati kehidupan lokal. Pengakuan kemudian dijadikan alat stimulus sebagai media tumbuhnya suasana pastisipatif. Dalam pendekatan partisipatif, masyarakat diposisikan sebagai mitra, bukan hubungan struktural atasan dan bawahan. Nah! Untuk lebih mendekatkan hubungan partisipatif dalam pemberdayaan masyarakat, ada satu konsep yang mujarab yaitu "menghargai". Penghargaan adalah penghormatan, pengakuan, reposisi dari sebutan masyarakat yang biasanya dipandang serba kurang, berubah menjadi sebutan yang terhormat. Ada aqualitas personal yang dibangun, bahwa Anda adalah sama dihadapan kami.

Dalam perkembangannya, muncullah pendekatan appreciative yang berasal dari suku kata appreciate dengan arti menghargai. Dimana dalam proses komunikasi pengembangan masyarakat dinyatakan bahwa suatu tindakan memahami sesuatu yang terbaik dalam individu atau dunai sekitarnya dengan memberi dukungan terhadap kelebihan, kesuksesan dan potensi di masa lalu maupun masa kini. Dari pendekatan itu kemudian diusahakan dengan melakukan suatu tindakan meng-ekplorasi dan menemukan potensi dengan cara mengajukan pertanyaan untuk

\footnotetext{
${ }^{2}$ Pemberdayaan dipakai untuk mrngureksi konsep pembangunan yang lebih menekankan aspek makro. Inti dari pemberdayaan adalah tumbuhnya perubahan perilaku masyarakat, dari satu kondisi ke kondisi yang lebih baik. (Oos, Pemberdayaan Masyarakat di Era Global, Alfabeta, Bandung, 2014, hlm. 2-3
} 
memperluas pandangan terhadap kemungkinan lahirnya potensi baru sebagai bahan pengembangan. Tindakan seperti ini disebut dengan pendekatan inquiry (Inggris ; inquire) dengan folus pendalaman pada suatu aspek yang dianggap lebih. Jadilah pendekatan ini dikenal dengan pendekatan penghargaan pada suatu aspek yang unik pada masyarakat atau biasa disebut dengan appreciative inquiry.

Untuk memudahkan memahaminya, akan penulis sajikan model pendekatan berbasis masalah dan pendekatan berbasis potensi. Dalam pendekatan pengembangan masyarakat berbasis appreciative inquiry, yang dilihat adalah pada aspek "apa yang ada dalam masyarakat itu sendiri untuk dikembangkan". "Yang ada" disini dijadikan obyek perhatian untuk diberikan stimulus, agar "yang ada" tetap milik masyarakat dan tidak dipandang sebagai sesuatu yang datang. Ia adalah kekayaan masyarakat itu sendiri, dimana pendamping hanya memberikan bantuan untuk lebih memaksimalkan apa yang ada. Pendekatan ini berbeda dengan pendekatan dengan konsep yang lebih mengedepankan pemecahan masalah. Dimana obyek dipandang sebagai entitas yang kurang sehingga selalu diawali dengan melakukan identifikasi masalah, analisa penyebab , analisis solusi, implementasi solusi dengan asumsi dasar bahwa fenomena sebagai persoalan. Dari konsep ini, maka kita menjadi terbiasa mendengar pernyataan pejabat atau tokoh terhadap fenomena yang terjadi dengan ungkapan, "kepada masyarakat kumuh dengan sebutan masyarakat marginal". Kepada masyarakat yang terkena narkoba, judi, peminum dengan ungkapan, "sampah masyarakat". Dengan masyarakat seperti yang terjadi di daerah Tubeket, dengan sebutan, "masyarakat tertinggal". Satu pendekatan, jika dinyatakan oleh pejabat menjadi kurang etis, dan terkesan mereka melupakan kewajibannya sebagai birokrat dan kemudian terkesan hubungan yang terjadi antara warga dan birokrat laksana atasan dan bawahan, seakan bawahan selalu dinaggap sumber masalah, sedangkan atasan dianggap sebagai pemecah masalah. Padahal, boleh jadi atasan-lah yang menjadi sumber utama masalah.

Dalam perkembangannya, karena setiap manusia ingin dihormati seiring dengan kesadaran yang tumbuh oleh Kewajiban Asasi Manusia (KAM) dan Hak Asasi Manusia (HAM) lahirlah satu kesadaran untuk lebih memanusiakan manusia. Maksudnya, manusia yang satu sama derajat dan potensinya dihadapan manusia yang lain. Kedudukan yang dimiliki oleh seseorang, sejatinya hanya untuk lebih memberikan manfaat dan bantuan 
bagi manusia yang lain, yang dianggap belum beruntung, namun memiliki potensi yang sama. Dikembangkanlah kemudian pendekatan yang lebih humanistik dengan sebutan "Appreciative Inquiry". Basis dari pendekatan ini adalah mengapresiasi "apa yang ada" dalam masyarakat, lalu berdasar apa yang ada ia melakukan serangkaian atau mengajak warga melakukan imanjinasi "apa yang mungkin" dilakukan jika ada seperti ini. Dari berbagai imajinasi yang berkembang, lalu warga diarahakan untuk menentukan "apa yang harus" dilakukan untuk sebuah aksi lapangan. Setelah itu warga diajak untuk lebih fokus lagi dalam memberikan perhatian terhadap peluangpeluang tersesbut sehingga mereka dapata menyusun "apa yang dapat" . Dasar dari pendekatan ini adalah adanaya asumsi secara umum bahwa suatu fenomena yang terjadi di masyarakat dipandang sebagai sebuah keajaiban, potensi yang perlu sentuhan stimulus agar berubah menjadi lebih positif dan bermanfaat. Tidak menempatkan suatu fenomena sebagai masalah, dan inilah filosofi dari appreciative inquiry bahwa fenomena harus dihargai.

Penelitian adalah penelitian lapangan plus, dengan makna yang seluas-luasnya. Yaitu lembaga donatur yaiktu Dewan Dakwah dengan cara menerjunkan petugas dakwah kelapangan dalam masa antara 2011-2019 dengan periode tugas satu tahun. Periode pertama diturunkan tenaga da'i pertama pada tahun 2011-2012 sebagai personal advan dengan tugas melakukan assesment. Pada tahun berikutnya, dikirim petugas kedua untuk melanjutkan rintisan dengan melakukan hal-hal yang mungkin sebagai basis penguat dan pilihan kegiatann unggulan. Sedangkan pada bulan ke 7 dari petugas kedua, dikirim peneliti (penulis) sebagai supervisi. Selama masa petugas berdakwah, supervisor melakukan pembimbingan dari jarak jauh, dengan cara mengkaji dan menelaah laporan-laporan peneliti berupa laporan tertulis dan lewat telepon sebagai bahan untuk didiskusikan dengan Tim yang ada di Pusat, yang selanjutnya hasilnya dipergunakan untuk melakukan aksi lapangan. Posisi da'i, selain sebagai penda'wah, dia sekaligus sebagai peneliti terhadap program yang dilaksanakan untuk memberdayakan masyarakat.

Pada penelitian ini akan dikumpulkan berbagai fenomena yang sedang terjadi dikehidupan masyarakat Tubeket, dengan fokus perhatian pada kegiatan yang menyangkut aktivitas pendidikan dan aktivitas ekonomi khususnya dalam hal pemenuhan kebutuhan pokok. Yaitu pemindahan kebiasaan masyarakat mencari sagu di hutan, berubah bercocok tanam padi di sekitar tempat tinggal mereka. Hal-hal lain yang ada dimasyarakat, akan 
ikut diungkapkan sebagai bagian dari kekayaan peradaban yang ada dikawasan ini dan juga untuk menghidupkan tulisan ini, agar pembaca bisa menghayati bagaimana masyarakat ini menjalani hari-harinya dengan apa adanya dan kemudian menemukan cara yang lebih layak dan terhormat. Tahun 2020 ini, rencananya masyarakat ini akan menikmati anak-anaknya studi dibangku kuliah.

\section{HASIL DAN DISKUSI}

Kepulauan Mentawai dapat juga disebut dengan Kepulauan Sikerei, maka tidak heran petugas lapangan disambut dengan kalimat "Selamat Datang Ke Bumi Sikerei", yang artinya Selamat Datang Ke Pulau Perdukunan. Sebutan Sikerei menjadi ciri khas adat masyarakat Kepulauan Mentawai dan kemudian identik dengan perilaku perdukunan khususnya adat masyarakat Dusun Tubeket. Walaupun da'wah sudah lama masuk ke dusun ini dan seluruh masyarakatnya beragama Islam, namun masih banyak yang memegang kuat adat tersebut. Hal tersebut karena minimnya dan boleh jadi nyaris tidak ada lagi pembinaan masyarakat dalam berbagai bentuk. Apakah pembinaan dalam bentuk pendidikan umum, maupun pendidikan agama.

Penyebutan Sikerei menggambarkan tentang kondisi komunal masyarakat yang jauh dari sentuhan kelayakan sebagai komunitas warga negara. Mereka mempercayai Allah tapi juga mempercayai dunia mistik sebagaimana daerah-daerah tertinggal yang lain di Indonesia. Percampuran kepercayaan ini disebabkan belum tuntasnya pembinaan dan masih kuatnya akar kebudayaan lokal yang ada di daerah. Kebudayaan lokal ini, selain juga perlu dikoreksi karena tidak logis, tapi juga seringkali menjadi sebab penghalang bagi kehadiran tata cara modern dalam mengubah masyarakat. Misalnya, tata cara bertani yang apa bila harus mengubah hutan menjadi persawahan dianggap melanggar aturan adat, dianggap mengubah hutan sebagai habibat asli. Apalagi dengan peralatan modern dan menentukan musim tanam yang tidak lagi memanfaatkan 'Sikerei' sebagai penentu musim panen. Hal-hal seperti, dikawasan ini masih dianggap tabu dan bermasalah, apalagi jika gagasan ini ditawarkan oleh tenaga da'wah, maka akan dianggap melawan wibawa Sikerei yang sudah mendominasi adat budaya lokal. Mereka masih sangat percaya dengan dukun saat ada peristiwa kematian, dimana setelah mayit dikebumikan, pada malam 
harinya semua pakaian simayit dibuang keluar rumah, lalu sang dukun membaca semacam mantra untuk mengusir roh simayit yang dianggap masih menempel dipakaian tersebut, tujuannya agar tidak mengganggu keluarganya yang masih hidup.

Kekuatan kepercayaan kepada Sikerei tersebut bisa dimaklumi, karena tingkat pendidikan masyarakat dusun Tubeket yang rata-rata hanya Sekolah Dasar (SD) dan hanya sedikit yang bisa menyelesaikanya sampai tamat. Warga jarang keluar atau menerima kedatangan orang luar, karena jauhnya kampung tersebut dari pusat kota. Hal ini sangat mempengaruhi pola pikir dan pola tindak mereka. Misalnya, mereka masih menganggap sekolah tidak penting, seolah-olah anak-anak dibesarkan hanya untuk membantu orangtuanya saja, ada yang merantau menjadi buruh bangunan dan perkebunan bagi laki-laki dan pembantu rumah tangga bagi perempuan. Bagi yang tidak merantau, mereka membantu mencari ikan kelaut atau kekebun. Jika sudah berani berumah tangga, maka mereka memilih pasangan dari kalangan mereka sendiri untuk menikah dan tinggal pula dikawasan tersebut sebagaimana orang tuanya. Pada tahun 2013 hanya ada satu lulusan SMP dan tigas lulusan SD yang kemudian membantu tenaga da'wah untuk terlibat dalam kegiatan pemberdayaan masyarakat.

\section{Peluang Dalam Penguatan Komunitas Tubeket}

Ada beberapa keunikan yang bisa dipotret dalam masyarakat Tubeket. Pertama, terkait pendidikan dimana anak-anak dusun Tubeket memiliki permasalahan yang tersendiri, kelas satu sampai tiga belajar apa adanya. Mereka dididik hanya satu orang guru utama yang jenjang pendidikannya tamat sekolah dasar dan tingkat pertama. Adapun kelas empat sampai lima harus melanjutkan studinya di Kecamatan Sikakap. Mereka yang masih kecil "terpaksa" hidup mandiri (Sewa rumah atau kamar, ngekos). Akibatnya, mereka sulit "dikontrol", baik itu dari segi pergaulannya maupun pendidikannya (khususnya agama) karena mereka merasa "bebas" jauh dari pantauan orangtua.

Untuk mnumbuhkan dinamis dalam belajar, anak-anak mendapatkan pelajaran umum dan agama. Sekolah tingkat dasar yang ada di Tubeket diindukken ke MIN (Madrasah Ibtidaiyah Negeri) dimana kegitan belajar harian dimulai dari jam 08.00-12.00 membantu mengajar di Dusun Tubeket, sedangkan untuk TPA (Taman Pendidikan Al-Qur'an) Dusun 
Tubeket dimulai setelah sholat ashar sampai jam 05.30. Kemudian dilanjutkan setelah sholat magrib sampai isya dan setiap hari Jum'at dan Ahad shubuh ada program tahfidz Al-Qur'an. Dari usaha ini, beberapa anak-anak sudah ada yang menyelesaikan juz 30 dan ada yang melanjutkan juz 1, sebahagian lagi ada yang hampir menyelesaikan juz 30 tergantung kepada kemampuan anak-anak. Selain itu ada pembinaan aqidah dan akhlak. Aqidah misalnya mengenal Allah sebagai Tuhannya dan akhlak misalnya menghormati orangtua dan berbicara yang baik. Salah satu prestasi yang dicapai anak-anak adalah Juara II putra-putri cabang tahfidz tilawah/non tilawah dan adzan pada acara MTQ tingkat kabupaten di Siberut Kepulauan Mentawai tahun 2013. Kemudian mengikuti Ajang Kompetisi Seni dan Olah Raga Madrasah (AKSIOMA) cabang pidato Bahasa Indonesia tingkat propinsi Sumatera Barat tahun 2013 mewakili Kabupaten Kepulauan Mentawai. Hal ini menjadikan kami bersemangat menggali potensi anak-anak untuk menjadi kader dimasa yang akan datang. Tahun ajaran 2019-2020 ini angkatan pertama dari pendidikan di Tubeket akan lulus dari Madrasah Aliyah Pesantren Sikakap yang juga diinisiasi oleh Dewan Da'wah dan sebagianya akan melanjutkan studi sarjana.

Kedua, mata pencaharian sehari-hari masyarakat dusun Tubeket pada umumnya bertani dan nelayan. Permasalahannya adalah, mereka lebih termotivasi mencari nafkah (uang) yang langsung menghasilkan dengan cara mencari ikan di laut. Itupun dengan hasil yang cukup terbatas karena masih dengan cara tradisional. Disisi lain, mereka memiliki tanah yang sangat luas dan kosong (tanah masih gratis tidak perlu membeli) namun kurang memiliki motivasi dalam mengolah tanah tersebut untuk menanam kebutuhan sehari-hari seperti; padi, cabe, sayur mayur dan yang lainnya. Alasannya karena terlalu lama menunggu hasil panennya dan sulit dalam perawatannya. Mereka "memaksa" diri untuk menjadi orang kampung yang berjiwa orang kota, semuanya dibeli. Yang unik misalnya, dikawasan ini banyak warga yang memiliki alat komuniaski "handpone" walaupun tidak bisa digunakan, hanya sekedar menjadi barang pajangan. Mengapa? Karena daerah ini tidak ada listrik dan sinyal handpon serta radio. Biaya hidup yang sangat tinggi (melebihi kebutuhan sehari-hari di Jakarta) seolah-olah tidak mereka pedulikan, sebenarnya tidak mampu, akan tetapi "dipaksa" untuk mampu. Bagaimana tidak, karena $99 \%$ semua barang-barang berasal dari Padang. Dengan kapal yang hanya masuk sepekan sekali dan jarak tempuh perjalanan memakan waktu selama 12 jam maka wajar semua harga barang- 
barang tersebut melambung tinggi. Padahal kalau masyarakat dusun Tubeket mau, tentunya kebutuhan mereka sehari-hari bisa terpenuhi dengan cara memanfaatkan tanah yang luas itu untuk bercocok tanam. Kalau pun mau bercocok tanam, mereka hanya menanam pisang, keladi dan ubi saja dan itupun hasilnya kurang memuaskan karena belum dikelola dengan baik dan apa adanya sebagaimana warisan dari leluhurnya.

Seperti telah dijelaskan diawal bahwa makanan pokok masyarakat Mentawai khususnya Tubeket adalah sagu dan keladi. Seiring dengan berjalannya waktu, masyarakat Tubeket khususnya anak-anak sudah lebih munyukai makan nasi sebagai makanan pokoknya. Disamping itu pula, untuk mendapatkan sagu sudah mulai jauh dan proses pembuatannyapun dibutuhkan waktu 2-3 hari dengan hasil yang diperoleh hanya cukup untuk persediaan makanan selama satu minggu, selanjutnya mereka harus mencari lagi dan begitulah seterusnya sehingga tanpa disadari masyarakat khususnya Ibu-ibu sudah mulai jenuh (lelah) dan diperparah lagi dengan harga beras yang cukup mahal. Dari kondisi inilah kami mengajak masyarakat untuk membuka lahan persawahan. Kami menjelaskan kepada mereka bahwa kita harus memanfaatkan sebaik-baiknya tanah yang luas dan kosong yang kita miliki dan jauh berpikir kedepan untuk kebutuhan pokok anak-anak kita. Awalnya kami mengalami sedikit kesulitan karena mereka sulit untuk diarahkan.

Namun dengan ajakan yang terus menerus dibantu penatua-penatua, Kepala Dusun dan pengurus Masjid maka akhirnya masyarakat mulai bersemangat terutama Ibu-ibu untuk membuka lahan persawahan tersebut. Mereka mulai mencari bibit ke tempat saudaranya masing-masing, ada juga lembaga yang membantu menyediakan bibit padi sebanya $20 \mathrm{~kg}$ dan dari pemerintah daerah $5 \mathrm{~kg}$ setiap kepala keluarga. Alhamdulillah akhirnya semua masyarakat turun ke sawah dan tidak ketinggalan kami juga ikut berpartisipasi membuka sawah. Areal persawahan yang kami garap \pm 20 Ha. Pada bulan April 2013 yang lalu Pengurus Dewan Da'wah beserta LAZIS Dewan Da'wah Pusat bersama segenap masyarakat telah menikmati hasil panen raya. Pada akhir bulan Mei-Juni 2013 yang lalu kami telah membuka kembali lahan tersebut. Apabila pada tahap pertama jenis dan usia bibit kami tidak sama dan waktu penanaman tidak serentak ditambah lagi serangan hama yang cukup parah dan perawatan yang kurang memadai maka pada tahap kedua ini kami sudah mulai menanam jenis dan usia bibit yang sama dan menanam secara serentak dengan tujuan 
mengurangi serangan hama. Dalam peristiwa tanam ini sebgaja dilakukan dengan mengajak seluruh warga, juga anak-anak untuk menumbuhkan dan memupuk rasa tanggung-jawab antar masyarakat terhadap suatu usaha bersama, yang kayaknya tidak mundkin bisa dilakukan. Kebersamaan juga untuk menghidupkan dan merayakan keberhasilan bersama.

Pada masa awal penanaman, kendala yang dihadapi warga adalah bibit padi yang tidak unggul karena berpengaruh dengan hasil panen, racun hama pianggang (walang sangit) dan alat penggiling padi masih secara tradisional (lesung) juga belum mendapatkan penyuluhan dari pemerintah daerah setempat. Oleh karena itu kami telah mengajukan proposal ke Pemerintah Daerah melalui Dinas Pertanian Kepulauan Mentawai dan Jakarta namun belum ada perkembangan. Walaupun demikian kami tetap berjalan apa adanya sesuai dengan kemampuan kami masing-masing.

Ketiga, untuk aspek kebersihan, sebahagian masyarakat masih mandi dan dan membuang air besar di tempat terbuka. Mereka belum terbiasa membuang kotoran ditempat khusus, dan menganggap tempat khusus pembuangan menjadi barang mahal. Warga Tubeket merupakan masyarakat yang cukup unik. Kami mengatakan seperti itu karena sebahagian besar dari mereka tidak memiliki WC juga sumur secara tertutup. Padahal keduanya merupakan kebutuhan pokok yang tidak bisa ditawar-tawar. Untuk mandi mereka pergi ke Litau (parit) yang sangat terbuka sedangkan untuk membuang air besar mereka pergi ke hutan-hutan atau kesungai. Yang menyedihkan sekali adalah Ibu-ibu yang mandi di tempat terbuka (parit) tidak menutup aurat secara sempurna sehingga dapat dilihat bagi orang-orang yang lalu lalang. Oleh karena itu kami membuat gerakan "Gali sumur dan buat WC", namun lagi-lagi mengalami kendala. Ajakan ini dianggap dingin saja mungkin karena sudah menjadi kebiasaan dan tidak ada yang harus dimalukan hanya satu atau dua orang saja yang antusias dengan gerakan ini. Kami sudah merangkul orang-orang yang kami anggap berpengaruh namun belum juga berhasil. Kami tidak mau berputus asa, maka kami membuat program baru yaitu membuat "Tempat Mandi dan WC Umum". Alhamdulillah kami mendapatkan dana dari sebuah lembaga sebesar Rp. 2.600.000, walaupun tidak banyak, dana ini menjadi langkah awal untuk menjalankan program tersebut. Dengan merangkul Kepala Dusun dan Pemuka Agama setempat, kami mengajak masyarakat untuk membangun tempat mandi dan wc umum dengan cara swadaya masyarakat. Kami mendapatkan tantangan yang cukup hebat, 
namun alhamdulillah, program ini dapat berjalan dengan baik walaupun masih ada yang pro dan kontra. Sistem kerja kami bagi menjadi tiga kelompok. Pertama, pengadaan papan dan sejenisnya. Kedua, pengadaan pasir dan sejenisnya. Ketiga, membersihkan lokasi dan membuat pondasi. Kemudian setiap kepala rumah tangga menyediakan 15 buah atap rumbia. Dengan dana tersebut kami membeli semen, paralon, kloset dan yang sejenisnya. Dalam proses pembangunan ini kami membelikan ransum (makanan dan minuman) apa adanya dari kantong sendiri dan ikut bekerja. Akhirnya proyek inipun selesai dengan ukuran 2 X 6 meter dan 4 kloset, dua untuk Ibu-ibu dan dua untuk Bapak-bapak dan sekarang mereka telah menikmati bangunan ini. LAZIS Dewan Da'wah Pusat juga turut membantu sebesar Rp. 2.000.000, dana ini rencananya akan kami gunakan untuk membangunan WC umum pada tahap kedua. Dengan adanya tempat mandi dan WC umum ini kami harapkan nantinya masyarakat menyadari akan pentingnya kebersihan.

Keempat, pengajian orang tua diadakan setiap hari Senin-Rabu setelah sholat shubuh membahas kitab Shohih Targhib wa Tarhib, hari Kamis dan Sabtu setelah sholat shubuh kitab Fiqh Shohih Sunnah. Setiap malam Jum'at dan Sabtu setelah sholat magrib pengajian Ibu-ibu dan Bapak-bapak membahas kitab Tauhid dan Fiqh dan belajar membaca AlQur'an setiap hari Jum'at setelah sholat Jum'at untuk Ibu-ibu.

Dalam proses pembinaan ini, da'i menghadapi beberapa kendala seperti sulitnya untuk membangun kesadaran masyarakat akan pentingnya menuntut ilmu, walaupun ada beberapa masyarakat yang antusias untuk mau belajar. Dampak dari pengajian ini, Bapak-bapak dan Ibu-ibu yang mengikuti program ini sudah mulai memahami dan menjauhi keyakinankeyakinan yang berbau kesyirikan, tahyul dan khurofat, bacaan dan tatacara whudu' dan sholat dan pengetahuan Islam lainnya. Bahkan ada sebahagian Ibu-ibu yang semangat belajar Al-Qur'an padahal ada diantara mereka yang buta huruf, mata mulai rabun, tidak bisa berbahasa Indonesia akan tetapi semua itu tidak menuyurutkan semangat mereka.

Kelima, mata pencaharian masyarakat adalah nelayan, akan tetapi mereka masih menggunakan perahu dayung yang sangat sederhana. Mereka tidak bisa pergi ke tempat yang lebih jauh dan hanya seputar muara saja, hal ini berpengaruh kepada hasil tangkapan mereka. Pertama-tama yang kami lakukan adalah membentuk kelompok nelayan itu sendiri kemudian membuat proposal. Alhamdulillah, ada sebuah lembaga yang siap 
membantu dana yang bersifat pinjaman lunak sebesar Rp. 31. 800. 000 untuk 13 orang yang akan digunakan untuk membeli mesin pompong. Akan tetapi, kelompok ini mengalami kendala yaitu masalah pembelian mesin tersebut. Dana yang ada hanya cukup untuk membeli mesin pompong saja sedangkan dana untuk transportasi dan konsumsi selama di Padang-Sikakap belum ada. Untuk menghadapi kondisi seperti ini kami mengajak pengurus dan anggota kelompok untuk bermusyawarah. Karena lemahnya perekonomian mereka (tidak ada dana) maka akhirnya kelompok inipun dibubarkan. Dengan tidak mengenal lelah kami tetap mengajak dan menjelaskan kepada masyarakat akan pentingnya kelompok nelayan ini dan akhirnya ada 10 orang yang menjadi anggota tetap. Selanjutnya kami mengajukan proposal ke Jakarta dan Dinas Kelautan dan Perikanan Kabupaten Kepulauan Mentawai. Alhamdulilllah usaha ini sudah mulai menunjukkan perkembangan yang positif walaupun hasilnya belum pasti. Alhamdulillah proposal kami di respon dengan baik oleh pusat melalui Dinas Kelautan dan Perikanan. Pihak Dinas menjelaskan kepada kami bahwa Kelompok Nelayan Simoile-moile Dusun Tubeket akan mendapatkan bantuan dana sebesar Rp. 100.000.000 untuk membeli alat tangkap nelayan. Mereka memerintahkan kepada kami untuk melengkapi data-data dan membuka rekening di Bank Nagari, kemungkinan dana tersebut akan cair bulan Oktober mendatang. Namun kami tegaskan disini bahwa sebelum dana tersebut masuk kerekening kelompok nelayan maka bisa dikatakan belum pasti (masih dalam proses).

Keenam, memaksimalkan Masjid Nurul Huda Dusun Tubeket sebagai pusat kegiatan musyawarah, pembinaan warga dan tentunya ibadah mahdhah. Ketujuh, menyiapan asrama anak pulau yang melanjutkan sekolah diluar pilai Tubeket. Kondisi anak-anak Dusun Tubeket yang melanjutkan sekolahnya di Kecamatan Sikakap sangat memprihatinkan, karena mereka tinggal tempat yang tidak layak seperti. Langkah awal dai adalah menindaklanjuti laporan yang ditulis oleh da'i yang ditugaskan oleh Dewan Da'wah Pusat ke dusun ini pada tahun 2011-2012 yang lalu dengan cara menulis kembali dan melaporkannya ke Dewan Da'wah melalui LAZIS Dewan Da'wah Pusat dan STID Mohammad Natsir. Untuk menyiapkan program tersebut, da'i berkongsi dengan pemuka masyarakat yang ada di Kecamatan Sikakap. Dalam kongsi tersebut tokoh lokal menyediakan bangunan fisik, sedangkan da'i membangun secara non fisik yakni membina anak-anak dan menjelaskan kepada orangtua mereka akan 
pentingnya Panti Asuhan ini. Akhirnya Panti Asuhan inipun berjalan, anakanak mendapatkan pendidikan dan pembinaan yang intensif. Kondisi anakanak sebelum dan sesudah masuk ke panti sangat jauh berbeda. Karena masih dalam tahap perintisan, yayasan ini banyak mengalami kendala seperti masih menyewa rumah, biaya sehari-hari dan lain sebagainya. Di yayasan ini kami telah menampung anak-anak sebanyak 27 orang dari berbagai dusun dan selebihnya dari Dusun Tubeket. Alhamdulillah LAZIS Dewan Da'wah Pusat telah membantu 2 unit lampu limar sewaktu-waktu digunakan apabila lampu mati, dana sebesar Rp. 3.000 .000 sebagai biaya operasional dan membangun asrama dalam bentuk wakaf tanah dan gedung.

\section{Proses Appreciative Inquiry}

Setelah kita mengikuti beberapa fenomena yang dianggap posistif melalui sentuhan stimulus dari da'i, selanjutnya akan kita paparkan bagaimana seluruh program yang telah dilakukan diproses melalui pendekatan penghargaan atau "Appreciative Inquiry". Alur kerja dari konsep ini adalah mengapresiasi "apa yang ada" dalam masyarakat, lalu berdasar apa yang ada ia melakukan serangkaian atau mengajak warga melakukan imanjinasi "apa yang mungkin" dilakukan jika ada seperti ini. Dari berbagai imajinasi yang berkembang, lalu warag diarahakan untuk menentukan "apa yang harus" dilakukan untuk sebuah aksi lapangan. Setelah itu warga diajak untuk lebih fokus lagi dalam memberikan perhatian terhadap peluang-peluang tersesbut sehingga mereka dapata menyusun "apa yang dapat". Dasar dari pendekatan ini adalah adanya asumsi secara umum bahwa suatu fenomena yang terjadi di masyarakat dipandang sebagai sebuah kejaiban.

Dalam kasus di Tubeket sejak awal memang sengaja petugas da'wah diberikan kesempatan untuk banyak menyerap tentang potensi dan peluang yang ada ditengah masyarakat. Untuk mendapatkan informasi yang cukup tentang aktovitas da', penulis akan berudahan mengkombinasikannya dengan 4 pendekatan ${ }^{3}$, yaitu ; tahap persiapan, tahap pencerahan, tahap imajinasi dan tahap pelaksanaan. Dalam prakteknya, apa yang dilakukan petugas da'wah adalah,

\footnotetext{
${ }^{3}$ Jordan E. Ayan, Bengkel Kreativitas, Kaifa, 1997, hlm. 64-57
} 
a. Pendekatan "apa yang ada" dalam masyarakat

Tahapan ini dikenal juga dengan tahapan persiapan. Selama berada di tengah masyarakat Tubeket, jika mengacu pada apa yang dilakukan kita dapat merasakan bahwa da'i mencoba menstimulus aktivitas masyarakat sebagai potensi.

dimana pekerjaan da'i mengumpulkan sebanyak mungkin informasi terkait aktivitas masyarakat. Untuk menggali hal tersebut, da'i banyak silaturahmi, mengobrol dan memberi umpan kepada masyarakat. Misalnya dalam hal pendidikan dan inilah rintisan kegiatan dengan pendekatan potensi masyarakat dijadikan umpan, dengan harapan terwujud kegiatan pendidikan yang basisnya adalah "dari warga, oleh warga". Mengapa demikian, karena tidak mungkin mendatangkan tenaga pendidik dengan kondisi yang ada karena banyak cerita dimana tenaga da'i tidak tahan berada didaerah ini yang sangat terbelakang dari berbagai lapangan, toh yang diperlukan dalam proses kegaitan belajar terutama diperuntukkan untuk anak-anak. Anak-anak didahulukan karena isu tentang anak akan dijadikan media komunikasi dengan orang tua terkait potensi-potensi yang lebih luas lagi. Pada tahan awal, da’i banyak mengajukan pertanyaan seputar, "apa di masyarakat diperlukan pendidikan", "Apakah ada diantara warga yang pernah memiliki pengalaman belajar", "apakah mungkin orang tersebut ikut dalam kegiatan belajar mengajar", "apa tingkatan sekolah yang perlu dibuat?", "sampai kelas berapa yang perlu dibuat". Beberapa pertanyaan ini bisa kita berikan jawaban, yang sekaligus jawaban ini kita carikan solusinya dari kalangan ini sendiri,

\begin{tabular}{|l|l|l|}
\hline & Pertanyaan & Jawaban yang didapatkan \\
\hline 1 & $\begin{array}{l}\text { "apa di masyarakat } \\
\text { diperlukan pendidikan", }\end{array}$ & $\begin{array}{l}\text { Untuk anak-anak sangat } \\
\text { perlu }\end{array}$ \\
\hline 2 & $\begin{array}{l}\text { "Apakah ada diantara } \\
\text { warga yang pernah } \\
\text { memiliki pengalaman } \\
\text { belajar", }\end{array}$ & $\begin{array}{l}\text { Ada yang sampai lulus } \\
\text { sekolah dasar dan tingkat } \\
\text { pertama }\end{array}$ \\
\hline
\end{tabular}




\begin{tabular}{|l|l|l|}
\hline 3 & $\begin{array}{l}\text { "apakah mungkin orang } \\
\text { tersebut ikut dalam } \\
\text { kegiatan belajar mengajar", }\end{array}$ & $\begin{array}{l}\text { Sangat mungkin dan layak } \\
\text { terlibat, karena orang } \\
\text { tersebut istri dari tokoh } \\
\text { masyarakat }\end{array}$ \\
\hline 4 & $\begin{array}{l}\text { "apa tingkatan sekolah } \\
\text { yang perlu dibuat?", }\end{array}$ & $\begin{array}{l}\text { Sekolah Dasar, kerana } \\
\text { jumlah anak lebih banyak } \\
\text { dibanding usia remaja dan } \\
\text { usia diatasnya termasuk } \\
\text { orang tua }\end{array}$ \\
\hline 5 & $\begin{array}{l}\text { "sampai kelas berapa yang } \\
\text { perlu dibuat". }\end{array}$ & $\begin{array}{l}\text { Kelas 1 samapai 3, karena } \\
\text { pada kelas 4 mereka akan } \\
\text { meneruskan sekolah negeri } \\
\text { yang ada di Kota Kecamatan }\end{array}$ \\
\hline 6 & $\begin{array}{l}\text { Perlu dibuatkan panti khusus } \\
\text { untuk tempat tinggal dan } \\
\text { pembinaan }\end{array}$ \\
\hline
\end{tabular}

b. Melakukan imajinasi "apa yang mungkin" dilakukan.

Pada tahap imajinasi, da'i terlibat dalam kondisi inkubasi yaitu melakukan semacam perenungan mendalam dan menyeluruh, diam sejenak untuk menghayati apa yang dialaminya. Karena da'i tidak saja sebagai peneliti tapi sekaligus sebagai penda'wah, maka ia tidak puas jika hanya melakukan observasi dan eksperiman yang sifatnya material saja. Ia juga melakukan kontak yang sifatnya metafisik, yaitu ber-munajad kepada Allah sebagaimna janji-Nya, "siapa yang sungguh-sungguh maka akan ada jalan" 4 dan "siapa yang bertaqwa maka Allah akan menjadi gurunya" 5 . Apa yang sebaiknya dilakukan untuk menangkap potensi tersebut. Dalam masa ini, masa diam ini sejatinya juga bekerja, namun pekerjaan tersebut dibatasi dari ruang publik yang luas, karena da'i ingin mengaitkan dengan keseluruhan potensi yang ada dimasyarakat. Pastilah, perenungan ini sebagaimana term inkubasi itu sendiri yang bermakna menyemai.

${ }^{4}$ QS. Al-Ankabut (29) ayat 69

${ }^{5}$ QS. Al-Baqarah (2) ayat 282 
Menyemai potensi yang ada dengan ide-ide solutif terhadap keadaan yang ada. Misalnya, perenungan siapa yang akan mengajar, direspon dengan stimulus "siapa yang pernah belajar". Harapanya, personal yang pernah belajar akan dapat diajak untuk ikut terlibat dalam proses belajar mengajar, menjadi guru, walaupun kesannya “jeruk makan jeruk". Lulusan SD mengajar anak SD. Tapi ini kan potensi, toh yang ajar anak SD kelas 1-3, dan itu mungkin dilakukan sebagaimana guru itu sendiri melakukannya kepada anak-anaknya sendiri yang hampir seusia.

Pada tahap ini, setelah lama merenung dan berdiskusi dengan pembimbing yang ada di Jakarta, da'i merasakan ada dorongan bagaimana melakukan pembinaan kepada bapak-bapak. Tapi skil yang dimilikinya tidak cukup untuk membantu fenomena yang sedang terjadi. Sebenarnya, skil da'i adalah da'wah melakukan pencerahan kepada warga, namun ada kendala yang dihadapi, dimana banyak warga khususnya laki-laki sering tidak ada dirumah pada waktu siang karena disibukkan dengan mencari ikan atau mencari sagu dengan waktu yang relatif lama. Maka dirasakan ada kejenuhan, karena setiap waktu hanya bertemu dengan anak-anak dan sepekan sekali dengan ibu-ibu. Sementara jika membina bapakbapak pada waktu malam, sarana lampu tidak cukup bisa menerangi forum pertemuan.

c. Menentukan “apa yang harus” dilakukan untuk sebuah aksi lapangan.

Setelah melakukan proses inkubasi, dengan berimajinasi "apakah yang bisa dilakulan", sampailah pada tahapan yang lebih serius untuk memilih dan menentukan aksi yang lebih nyata. Tapi untuk sampai pada menentukan pilihan, karena posisi da'i bukanlah tokoh sentral yang dapat menveto putusan, maka da'i mengajak bermusyawarah. Mulailah da'i, berkonsultasi dengan kepala adat, tetua kampung yang sangat disegani oleh warga. Dan dari pak tetua inilah kemudian disampaikan kepada kepala kampung dan kepala kampung memilih beberapa laki-laki yang selama ini banyak berperan dalam setiap kegiatan.

Pokok bahasan yang diajukan adalah tentang gagasan tanam padi disekitar kampung untuk mengurangi bepergian bapak-bapak ke hutan mencari sagu. Kendala yang paling rumit adalah, 
"bagaimana menyakinkan warga bahwa mereka dan tanah ini cocok untuk dijadikan area persawahan", dimana kampung ini belum pernah memiliki sejarah tanam padi. Selain itu, tidak satupun petani memiliki kemampuan itu, demikian juga sang da’i itu sendiri. Musyawarah, sebagaimana yang dilaporkan da'i- cukup alot, bahkan da'i dianggap 'gila' karena idenya. Ide ini dikenalkan kepada warga setelah 7 bulan sang da'i kedua melakukan pendampingan dikawasan ini dan telah merintis kegiatan pendidikan anak dan ibuibu.

Jadi, walaupun da'i dianggap "gila" tapi warga merasa tertolong jika ide ini bisa diwujudkan. Ada dua keuntungan yang didapat, lakilaki tidak lagi bepergian jauh untuk mencari sagu dan makan nasi beras akan terwujud dengan mudah, karea selama ini nasi beras adalah barang mahal. Untuk mengatasi kesulitan, bagaimana cara menanam padi dan merawatnya diusulkan untuk meminta dinas pertanian menjadi pendamping. Yang paling pokok dalam musywarah tersebut adalah, "apakah gagasan ini penting" dan "apakah warga setuju untuk memberikan tanah dan mengubahnya menjadi lahan persawahan". Sebagai tahap awal, maka tanah yang dipakai adalah tanah adat yang masih berupa hutan.

Untuk mengubah hutan ke lahan sawah diperlukan gotong royong warga berhari-hari, karena masih banyak pohon besar dan semak-semak yang lebat. Soal air, alhamdulillan bukan perkara sulit karena dilahan terebut, dilewati aliran sungai air yang bersih sebagai bahan air minum dan kebutuhan sehari-hari warga. Peran da'i dalam proses ide/gagasan, merenungkan secara mendalam, mengkomunikasikan secara partisipatif, me-musyawarahkan, memberikan contoh/eksperimen dan melaksanakan, menjadi ujung tombak dari keseluruhan program. Paling krusial adalah bagaimana da'i mendemonstrasikan gagasan tersebut berupa memberikan contoh, misalnya memulai memotong semak-semak, mengatur lahan, mencangkul, melakukan pembibitan, memindahkan bibit dnan lain-lain, diposisikan sebagai media komunikasi kepada masyarakat. Justru proses inilah, jika didasarkan pada laporan yang memerlukan 'ketelatenan' khusus, hal ini sebagaimana masyarakat desa, dimana warga akan bergerak kalo sudah diberikan contoh konkretnya. 
d. Menyusun "apa yang dapat” dilakukan .

Tahap pelaksanaan sampai pada kesimpulan, yaitu memilih bersawah, dimana opsesinya jika tanah sawah berfungsi samapai panen maka warga akan memiliki pengalaman bagaimana mengolah sawah padi dan itu artinya ada solusi terhadap perubahan potensi hutan menjadi lahan padi. Hal ini juga sebagaimana laporan da'i, dimana ia mengutarakan keinginanya bisa menyapa bapakbapak. Setelah bercerita, bagaimana kesulitan mengumpulkan bapa-bapak karena soal tidak adanya waktu luang, waktu habis untuk mencari sagu, maka pembina di Jakarta mengusulkan agar mulai dijajaki, mungkinkah mengubah tanah hutan yang dekat dengan permukinan dijadikan alternatif persawahan. Mulailiah da'i melakukan bincang-bincang dengan tokoh dan warga terkait ide ini. Pada awalnya, dai dianggap "gila", karena selama ini belum pernah ada aktifitas dan keterampilan menanam padi. Da'i coba meyakinkan, dengan menggandeng dinas pertanian untuk memberikan penyuluhan, dan singkat cerita berhasilllah da'i mewujdukan hal tersebut. Sebagian warga mendukung aktivitas ini dan pada pertengahan tahun 2013 tanaman padi warga dirayakan untuk pertamakalinya dikawasan tersebut.

Gagasan da'i memilih soal stimulus aspek pangan, sebenarnya hanyalah media antara untuk memberikan penguat pada aspek pendidikan dan program-program yang lainya. Aspek pangan bukan utama, walaupun secara kasat mata program ini memerlukan upaya yang tidak ringan, yang dimulai dari membuat perencanaan, sampai pada aksi nyata. Pemberdayan dalam skala mikro dalam komunitas ini memang tidak mudah. Kita misalnya bisa melihat bagaimana upaya Dewan Dawah yang sebenarnya tidak saja hanya melihat aksi lapangannya, tapi juga bisa kita lihat bagaimana upaya lembaga ini dalam tahap proses menyiapkan tenagatenaga da'inya. Mendidik mereka dalam suasana kampus berasrama dengan formalitas legal, juga sentuhan pembinaan dalam nuansa kekeluargaan.

Dengan melihat indikator panen padi, kita bisa membuat satu asumsi bahwa usaha ini dipadang berhasil. Sekurangnya kegiatan ini berhasil mengubah pola pikir masyarakat yang hanya mengandalkan alam, yaitu hutan sebagai sumber kehidupan. Keberhasilan berikutnya adalah memindahkan, sumber makan mereka yang dahulunya di hutan, digeser 
dan dipindahkan di dekat kampung tempat tinggal. Hasil akhrinya, karena tempat bertani menjadi dekat kampung, maka kesempatan untuk banyak bertemu dan berkumpul dengan keluarga menjadi lebih lama dan sering. Bagi da'i, keuntungan non-finansialnya adalah peluang waktu untuk mendidik menjadi lebih mungkin dilakukan. Cita-cita berdakwah dalam arti yang sesungguhnya menjadi lebih nyata. Pada aspek kultural, sang da'i menjadi ikon dan tokoh baru, karena berhasil memberikan peluang kepada masyarakat dengan cara memberikan penghargaan atas ide-idenya dalam menyelesaikan kesulitan pangan.

\section{KESIMPULAN}

Dasar dari pendekatan ini adalah adanya asumsi secara umum bahwa suatu fenomena yang terjadi di masyarakat dipandang sebagai sebuah kejaiban. Dari sisi pendampingan, da'i menjadi aktor yang aktif memberikan penghargaan terhadap aktivitas dan potensi masyarakat dengan stimulus program yang lebih baik. Dari sisi pesan, tahapan-tahapan komunikasi bisa dilakukan dan dilewati dengan baik, melalui indikator keterlibatan masyarakat terhadap stimulus pertanyaan yang biasa digunakan dalam pendekatan appreciate inquiry yaitu, "Apa yang ada, apa yang mungkin, apa yang dapat, dan apa yang harus".

Pedekatan dengan konsep menghargai, cukup efektif untuk menumbuhkan kesadaran masyarakat untuk berubah dan terlibat menggerakkan perubahan. Dalam hal perubahan pola pikir terkait pentingnya pendidikan dan perubahan pola pemenuhan bahan makan dari sagu ke beras, menjadi tolok ukur keberhasilan program pemberdayaan. Hasilnya, terhadap perubahan yang mereka lakukan, berdampak pada kemandirian dan penerimaan terhadap pola baru yang lebih modern. Kuncinya, sebagaimana yang dilakukan oleh da'i adalah penghargaan atas potensi yang mereka miliki, baik potensi manusianya, ataupun potensi alamnya sebagai media menjalani kehidupannya.

\section{DAFTAR PUSTAKA}

Adi, Isbandi Ruminto, Intervensi Komunitas, RajawaliPress, Jakarta, 2008 Amahzun, Muhammda, Manhaj Da'wah Rasulullah, QisthiPress, 2004 
Anwas, Oos M., Pemberdayaan Masyarakat Era Global, Alfabeta, 2014

Ayan, Jordan E., Bengkel Kreativitas, Kaifa, 1997

Bakri, Maskuri, Pemberdayaan Masyarakat RRA dan PRA, Visipress, 2017

Ife dkk, Jim, Community Development, Pustaka Pelajar, Yogyakarta, cetke III, 2008

Laporan Kafilah Da'wah Putri, STID M Natsir 2019

M. Rogers dkk, Everett, terjemah Abdillah Hanafi, Memasyarakatkan ideide baru, Pent. Usaha Nasional, Surabaya, 1987

Machendrawaty dkk, Nanih, Pengembangan Masyarakat Islam, Rosda, Bandung, 2001

Natsir, Mohammad, Fiqhud Da'wah, Media Da’wah, Jakarta, cet-ke XIII, 2006

Sumodiningrat, Gunawan, Pemberdayaan Masyarakat, Gramedia, 1999 